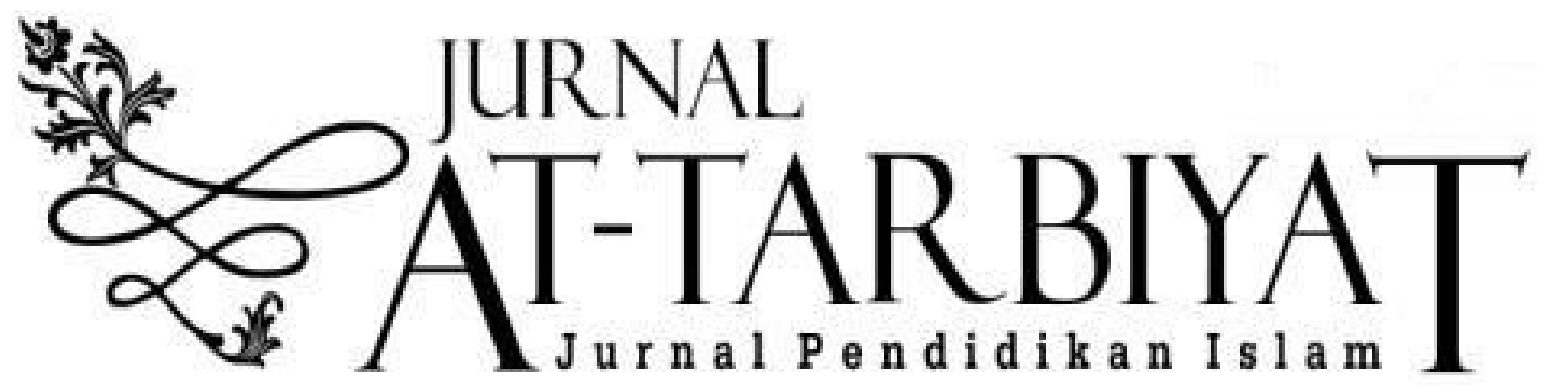




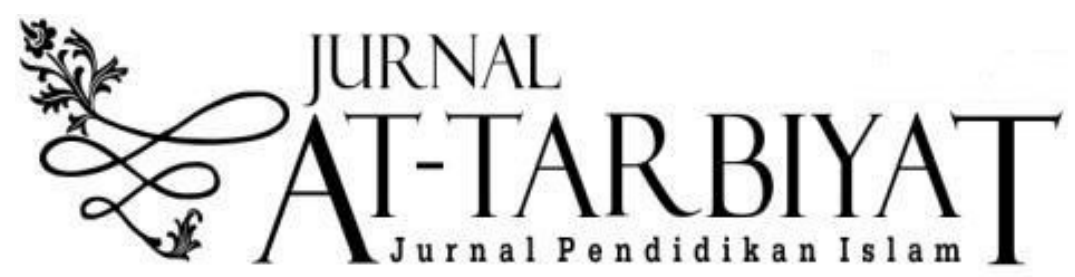

Editorial Team:

Editor in-Chief

Adi Wibowo, STAI An- Nawawi

Purworejo

\section{Editorial Board}

Badrudin, UIN Sunan Gunung Djati Bandung

Imam Machali, UIN Sunan Kalijaga Yogjakarta

Sri Rahmi, UIN Ar-Raniry Banda Aceh

A.Jauhar Fuad, IAI Tribakti Kediri

\section{Managing Editor}

Muhlil Musolin, STAI An- Nawawi

Purworejo

\section{Editor}

Ita Nurmala Sari, STAI An- Nawawi

Purworejo

Ahmad Syafi'i, UIN Sunan Kalijaga

Yogjakarta

Ulumuddin, Unwahas Semarang

Dwi Puji Lestari, STAI Al Hasyimiyyah Jakarta

Sri Sujarotun, STAI An- Nawawi Purworejo

Ali Murfi, UIN Sunan Kalijaga Yogjakarta

\section{Editorial Assistant}

Isnaini, STAI An- Nawawi Purworejo

Mujasim, STAI An- Nawawi Purworejo

\section{Alamat Redaksi:}

Prodi Manajemen Pendidikan Islam, STAIAN Purworejo

Jl. Ir.H. Juanda No. 1 Berjan, Gebang Purworejo 54191 Jawa Tengah»

Tel / fax : (0275)3128428. e-mail: jurnalattarbiyat@gmail.com http://jurnal.staiannawawi.com/index.php/At-Tarbiyat 


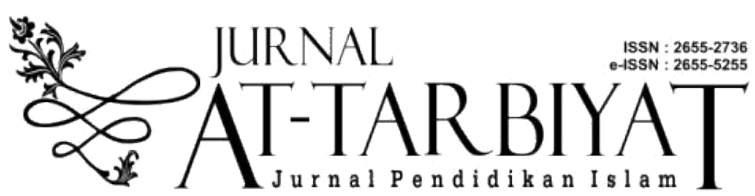

http://jurnal.staiannawawi.com/index.php/At-Tarbiyat

\title{
PERAN PESANTREN DALAM PENDIDIKAN RESOLUSI KONFLIK KEAGAMAAN
}

\section{Sigit Santoso}

IAIN Syekh Nurjati Cirebon

lavonche@gmail.com

\begin{abstract}
Abstrak
Artikel ini mengkaji tentang peran pesantren dalam pendidikan resolusi konflik. Konflik yang terjadi di beberapa daerah di Indonesia harus diupayakan solusinya, agar terbangun kehidupan masyarakat Indonesia yang damai. Salah satu cara membangun perdamaian adalah bagaimana merubah pandangan masyarakat tentang konflik yang semula merupakan suatu musibah menjadi sarana untuk pemberdayaan dan pembelajaran bagi masyarakat. Hal yang demikian ini seluruh elemen masyarakat dituntut untuk terlibat guna memberikan penyadaran, salah satu diantaranya adalah pesantren. Tujuan dari kajian ini adalah Pesantren mempunyai peranan sebagai pendorong aktif untuk melakukan proses resolusi konflik sehingga memampukan warga pesantren dan masyarakat agar dapat mengelola persoalannya sendiri. Hasil dari kajian pustaka ini adalah pesantren mempunyai harapan besar dalam program pendidikan yang berkaitan dengan resolusi konflik diantaranya pembelajaran dialog antar agama, mediasi konflik, dan pendidikan perdamaian (pelatihan manajemen konflik, pendidikan perdamaian untuk pemuda dan remaja, dan pengembangan pendirian lembaga).
\end{abstract}

Kata Kunci: Pesantren, Pendidikan, dan Resolusi Konflik

\section{Abstract}

This paper is study of the role of Pesantren in conflict resolution education Conflicts that occur in several regions in Indonesia must be efforted to be resolved, in order to build peaceful life of Indonesian people. One of the way to build peace is to change the community's perspective from the view of conflict as a loss, threat and sign of failure, to the view that conflict is also functional and can be a means of community empowerment and advancement. This requires an awareness of all elements of society to be involved in it, one of which is the Pesantren. The aim of this paper is that the Pesantren has an active role as a motivator to carry out a conflict resolution process so that the Pesantren community and the community can manage their own problems. The results of this literature study are that Pesantren are expected to have a variety of educational programs related to peace issues, interfaith dialogue, conflict 
mediation, and peace education (conflict management training, peace education for youth, and the development of institutional establishment).

Keyword: Pesantren, education and conflict resolution

\section{PENDAHULUAN}

Indonesia merupakan negara yang rawan akan konflik, dikarenakan Indonesia merupakan negara yang mempunyai ribuan pulau, banyak suku, ras, maupun agama. Konflik yang terjadi di Indonesia secara umum berkaitan dengan isu-isu ideologi, perbedaan keyakinan, agama, budaya dan isu moralitas. Misalnya:Konflik sosial yang terjadi di Distrik Kwamki Narama Mimika menyebabkan 12 orang meninggal dunia. Pemicu konflik adalah adanya aksi penganiyaan yang terjadi pada tanggal 12 november 2017 terhadapp Dedi Kiwak hingga meninggal dunia. Sehingga penganiyaan tersebut mengakibatkan dua kelompok dua kelompok di Kwamki Narama terlibat bentrok menggunakan senjata tradisional berupa busur panah hingga April 2018. ${ }^{1}$ Di Ambon, konflik yang terjadi dilakukan seorang pemuda dari pribumi yang beragama kristen yang berasal dari daerah Mardika dengan seorang pemuda nonpribumi yang beragama Islam dari daerah Batumerah. ${ }^{2}$ Konflik di Cikeusik, konflik yang terjadi adalah penyerangan jamaah Ahmadiyah oleh sekelompok orang yang berjumlah sekitar 2000 orang. ${ }^{3}$ Hal ini ditimbulkan oleh gesekan antar kelompok keagamaan, sigregasi sosial berdasarkan etnis, kekeringan spiritual,perebutan wilayah ekonomi dan terkikisnya nilai-nilai budaya Indonesia yang merupakan penyebab terjadinya kerentanan konflik. Dari berbagai kerentanan konflik tersebut menunjukkan bahwa di beberapa wilayah di Indonesia memiliki potensi konflik yang besar dalam kehidupan sosial bermasyarakat.

Munculnya kerentanan konflik dibeberapa daerah di Indonesia harus diupayakan solusinya, agar terbangun kehidupan masyarakat Indonesia yang damai. Salah satu cara membangun perdamaian adalah mengajak masyarakat untuk mengubah pandangan mereka tentang konflik dari pandangan musibah yang merugikan menjadi pemberdayaan, pembelajaran dan pemajuan bagi mereka.. Dengan cara pandang yang demikian ini diharapkan penyelesaikan konflik yang ada di masyarakat dapat dilakukan dengan kemampuan yang maksimal untuk menghindari adanya ketidakadilan dan kekerasan. Hal demikian biasa disebut dengan

${ }^{1}$ https://regional.kompas.com/read/2018/12/29/19451891/selama-201812-orang-meninggal-dunia-akibat-konflik-sosial-di-mimika

2 Masykur Wahid, "Resolusi Konflik Dan Islam Nusantara: Memromosikan Dialog Antar Budaya Dan Rekognisi Sosial," REFLEKSI 15, no. 02 (2016): 139-224.

3 Wahid.

141 Vol. 2, No. 2, Juli - Desember 2019 
transformasi konflik. ${ }^{4}$ Secara umum transformasi konflik berkaitan dengan usaha mencegah terjadinya konflik dengna cara mengubah struktur konflik menjadi struktur damai, baik dalam ranah budaya, ekonomi, politik dan nilai. ${ }^{5}$

Hal yang demikian harus ada kesadaran semua elemen di masyarakat untuk dilibatkan. Disinilah peran pesantren sebagai bagian dari masyarakat yang mempunyai peran yang sangat strategi. Pesantren mempunyai peranan sebagai pendorong aktif untuk melakukan proses transformasi konflik. Pesantren diharapkan mempunyai berbagai progam pendidikan yang kurikulumnya berkaitan dengan resolusi konflik, mediasi konflik, dialog antar agama, dan pendidikan perdamaian. Hal ini dimaksudkan untuk memampukan warga pesantren dan masyarakat untuk mengelola persoalannya sendiri. Berdasarkan latar belakang tersebut, tulisan ini akan menjelaskan peran pesantren dalam resolusi konflik.

\section{A. Pembahasan}

\section{Resolusi Konflik}

a. Definisi Konflik

Konflik (conflict) menurut bahasa berarti saling memukul yang dalam bahasa latinnya adalah confegere. Konflik merupakan sebuah tindakan yang dilakukan oleh salah seorang yang mengakibatkan terhalangi, terhambat atau terganggu oleh pihak lain yang dalam hal ini dapat terjadi antar kelompok masyarakat maupun dalam hubungan antar pribadi. ${ }^{6}$ Hal ini sejalan dengan pendapat Morton Deutsch mengatakan bahwa resolusi konflik adalah interaksi sosial antar individu atau kelompok lebih dipengaruhi oleh perbedaan daripada oleh persamaan. ${ }^{7}$ Sedangkan menurut Scannellkonflik adalah suatu hal alami dan normal yang timbul karena perbedaan persepsi, tujuan atau nilai dalam sekelompok individu. ${ }^{8}$ Hunt danMetcalf membagi konflik menjadi dua macam, yaitu intrapersonal conflict (konflik intrapersonal) dan interpersonalconflict (konflik interpersonal).

${ }^{4}$ Lisa Schirch, Strategis Peace Building (Goodbook: Intercourse PA. 17534) hlm. 50 ; Juga lihat Albert Fiadjoe, Alternative Dispute Resolution: Developing Word Perspective (London: Covendish Publishing Limited, 2004) hlm.8.; juga lihat Alo Liliweri, Prasangka dan Konflki: Komunikasi Lintas Budaya Masyarakat Multikultur (Yogjakarta: LKIS, 2005), hlm. 316. Juga lihat Lihat John Paul Lederach, Conflict Transformation (Intercourse: Good Books, 2003) hlm. 5

${ }^{5}$ Dewi Fortuna Anwar dkk (ed.), Konflik Kekerasan Internal: Tinjauan Sejarah, Ekonomi, Politik dan Kebijakan di Asia Pasifik (Jakarta: Yayasan Obor Indonesia-LIPI dan LASEMA-CNRS, 2004), hlm. 130-131

${ }^{6}$ Antonius Atosokhi Gea, dkk., Relasi Dengan Sesama. (Jakarta: Elex Media Komputindo, 2002), hlm. 175.

${ }^{7}$ Bunyamin Maftuh, Pendidikan Resolusi Konflik: Membangun Generasi Muda yang Mampu Menyelesaikan Konflik Secara Damai. (Bandung: Program Pendidikan Kewarganegaraan, Universitas Pendidikan Indonesia, 2005), hlm. 47

${ }^{8}$ Scannell, The Big Book of Conflict Resolution Games. (United States of America: McGraw - Hill Companies, Inc 2010), hlm. 2 
Konflik intrapersonal adalah konflik yang dialami oleh diri seseorang sendiri, misalnya ketika keyakinan yang dipegang oleh seseorang berlawanan dengan nilai budaya masyarakat, atau keinginannya tidak sesuai dengan kemampuannya. Jenis konflik ini adalah bersifat psikologis, yang apabila tidak bisa diatasi dengan baik dapat menggangu kesehatan jiwanya atau kesehatan mental (mental hygiene) orang yang bersangkutan. Sedangkan konflik interpersonal ialah konflik yang terjadi antar perseorangan. Konflik ini terjadi dalam setiap lingkungan sosial, seperti dalam keluarga, kelompok teman sebaya, sekolah, masyarakat dan negara. Konflik jenis ini dapat berbentuk konflik antar perorang dan kelompok, baik di dalam sebuah kelompok (intragroup conflict) maupun antar kelompok (intergroup conflict). ${ }^{9}$

b. Resolusi konflik

Resolusi konflik yang dalam bahasa Inggris disebut denganconflict resolution mempunyai banyak makna dan para ahli yang fokus meneliti tentang konflik memaknainya dengan berbeda-beda.Menurut Levine dalam Webster Dictionary mengatakan bahwaresolusi adalah (1) tindakan mengurai suatu permasalahan, (2) pemecahan, (3) penghapusan atau penghilangan permasalahan. ${ }^{10}$ Sedangkan menurut Weitzman \& Weitzman mendefinisikan resolusi konflik sebagai sebuah tindakan pemecahan masalah bersama (solve a problem together). ${ }^{11}$ Kemudian menurut Fisher et al menjelaskan bahwa resolusi konflik adalah usaha menangani sebab-sebab konflik dan berusaha membangun hubungan baru yang bisa tahan lama diantara kelompok-kelompok yang berseteru. $^{12}$ Mindes berpendapat bahwa resolusi konflik merupakan kemampuan untuk menyelesaikan perbedaan dengan yang lainnya dan merupakan aspek penting dalam pembangunuan sosial dan moral yang memerlukan keterampilan dan penilaian untuk bernegoisasi, kompromi serta mengembangkan rasa keadilan. ${ }^{13}$ Dari teori yang dipaparkan diatas dapat ditarik kesimpulan bahwa resolusi konflik adalah cara seseorang memecahkan dan menyelesaikan persoalan yang dihadapi dengan orang lain secara sukarela. Resolusi konflik

${ }^{9}$ M. Hunt P, and Metcalf, Ratio and inquary on Society's Closed Areas, in Educating The Democratic Mind (W. Partner). (New York: State University of New York Press, 1996).

${ }^{10}$ Levine, Webster Dictionary, (1998) hlm. 3

${ }^{11}$ Deutsch Morton, and Peter T. Coleman, The Handbook of Conflict Resolution, Theory and Practice. (San Fransisco: Jossey-Bass Publisher, 2006), hlm. 197

${ }^{12}$ Fisher, Simon, dkk. Mengelola Konflik: Keterampilan \& Strategi Untuk Bertindak. (Jakarta: The British Council, 2001), hlm. 7

${ }^{13}$ Mindes, Gayle. Teaching Young Children Social Studies (United States of America: Praeger Publishers. 2006), hlm. 24

143 Vol. 2, No. 2, Juli - Desember 2019 
merupakan jalan menyelesaikan konflik dengan cara yang lebih demokratis yang memberikan kesempatan terhadap orang-orang yang berkonflik untuk menyelesaikan persoalan mereka oleh mereka sendiri atau dengan melibatkan orang lain sebagai pihak ketiga yang dapat membantu mereka untuk menyelesaikan masalah.

2. Pesantren

Pondok pesantren merupakan lembaga pendidikan Islam di Indonesia yang ada sejak masa-masa awal penyebaran Islam oleh para wali sembilan di tanah nusantara, dan terus bertahan melewati berbagai masa hingga sekarang. Agaknya, pesantren ini berhasil menghadapi berbagai problem dan konflik yang ada, baik yang kecil sampai yang besar, bahkan dari tekanan para penjajah dalam masa waktu yang tidak sebentar. Semua itu membuktikan bahwa pesantrenadalah slah satu lembagapendidikan yang kokoh dalam mengabdikan dirinya untuk memberikan pendidikan bagi bangsa ini, utamanya pendidikan Islam. tidak dapat dielakkan lagi bahwa pesantren adalah sistem lembaga pendidikan yang mengakar sangat kuat dan paling besar yang asli dari Indonesia. Pesantren sudah sangat berpengalaman dalam menyelenggarakan pendidikannya terutama pendidikan keagamaan.Sebagai bagian dari struktrur pendidikan di Indonesia, pesantren menjadikan Islam sebagai cara hidup bagi para santrinya dan menyelenggarakan pendidikan dengan sistem tradisional. ${ }^{14}$ Pesantren dengan sistem tradisionalnya adalah lembaga pendidikan yang mengacu pada pemahaman, pendalaman, penghayatan dan pengamalan ajaran agama islam dengan mengutamakan perilaku yang baik atau akhlak al karimah dalam kesehariannya. ${ }^{15}$ Menurut Amin Haedari pesantren mempunyai tiga fungsi yaitu transmisi/pengoperan keilmuan islam (transmission of isalmic knowledge), memelihara tradisi islam (maintenance of islam tradition) dan pembinaan calon-calon ulama (reproduction of ulama). ${ }^{16}$

Bangsa Indonesiapunya harapan yang sangat besar terhadap pesantren untuk ikut andil dalam menyelesaikan konflik yang ada pada bangsa ini. Oleh karena itu pesantren harus menyiapkan kader santrinya untuk menjadi pendamai bagi siapapun dengan bekal program resolusi konflik. Dengan demikian pesantren berpegang

${ }^{14}$ Amin Haedari, Masa Depan Pesantren Dalam Tantangan Modernitas dan Tantangan Kompleksistas Global (Jakarta: IRD Press, 2006), hlm 14

${ }^{15}$ Mastuhu, Dinamika sistem pendidikan pesantren; suatu kajian tentang unsur dan nilai sistem pendidikan pesantren (Jakarta: INIS, 1994) hlm. 55

${ }^{16}$ Jamal Ma'mur Asmani, Dialektika Pesantren Dengan Tuntutan Zaman dalam Menggagas Pesantren Masa Depan, Geliat Suara Santri Untuk Indonesia Baru (Yogyakarta: Qirtas, 2003) hlm.25, lihat juga KH. Sahal Mahfudz, Nuansa Fiqh Sosial (Yogyakarta; LkiS, 1994) hlm 28 
teguh pada lima dasar asas pemberdayaan masyarakat yaitu pertama, warga masyarakat ditempatkan oleh pesantren sebagai subyek/pelaku yang aktif bukan obyek/sasaran dalam program. Kedua,sebagai upaya penguatan potensi lokal yang dimiliki pesantren bersama masyarakat menyusun program untuk peningkatan jejaring sosial, tokoh dsb. Ketiga, pemberlakuan fungsi manajemen (perencanaa, organisasi, pelaksanaan, refleksi dan evaluasi) semaksimal mungkin dengan melibatkan sejak awal partisipasi warga masyarakat. Keempat, untuk meningkatkan kesadaran masyarakat maka program disusun secara bersama-sama.Kelima, program pemberdayaan masyarakat dilaksanakan secara berkelanjutan. ${ }^{17}$

3. Peran Pesantren Dalam Pendidikan Resolusi Konflik

a. Pendidikan Dialog Antar Agama

Pendidikan dialog disini tidak dimaksudkan untuk beradu pendapat tentang kebenaran pada masing-masing agama sehingga yang terjadi adalah adanya kemenengan dan kekalahan. A. Mukti Ali mengemukakan bahwa dialog agama adalah menyerahkan hak setiap orang untuk menjalankan keyakinannya dan menyampaikan kepada orang lain.Tujuan dari dialog agama yang dilakukan oleh antar pemeluk agama dengan mempertemukan hati dan pikirannyauntuk mencari kebenaran dan saling bekerjasama dalam menyelesaikan persoalan-persoalan yang dihadapi secara bersamasama. ${ }^{18}$ Dalam hal ini dialog antar agama mengarahkan bagi pemeluk agma untuk memecahkan persoalan-persoalan yang dihadapi besama. Hal ini diistilahkan Muji Sutrisno dengan dialog agama dalam kerangka humanisasi. ${ }^{19}$ Artinya dialog tersebut berisi tema-tema besar yang berkaitan dengan kemanusian, misal; kemiskinan, kependudukan, hak asasi manusia (HAM), lingkungan hidup, pendidikan, krisis moral, dan sebagainya yang nantinya secara bersama antar pemeluk agama diupayakan solusinya atau jalan keluarnya.

Dialog agama merupakan dialog yang dilakukan oleh berbagai tokoh agamawan ${ }^{20}$ Dengan adanya dialog diharapkan dapat memberikan keterbukaan pada seluruh peserta dialog sehingga mereka merubah cara pandang mereka dalam berkomunikasi

${ }^{17}$ Dian Nafi’ (dkk), Praksis Pembelajaran Pesantren. (Yogyakarta: Forum Pesantren dan Institute For Training and Development (ITD), 2007), hlm 13.

${ }^{18}$ Dadang Khamad, Sosiologi Agama, (Bandung: Remaja Rosdakarya, 2004) hlm. 177

${ }^{19}$ Andito (ed.), Atas Nama Agama, (Bandung: pustaka Hidayah, 1998), hlm. 333337.

${ }^{20}$ Budhi Munawar Rahman, Pluralism Dan Dialog Antara Agama:Paradigma Teologi Eksklusif, Inklusif dan Pluralis, dalam Abdul Hakim dan Yudi Latif (peny), Bayang-bayang Fanaitisme; Esai-Esai untuk mengenang Nurcholis Madjid, Jakarta : Paramadina, 2007 hlm. 321. 
antara satu dengan yang lainnya dengan sikap yang tidak saling curiga, sehingga mereka akan memberikan pemahaman keyakinan, pemikiran dan persolan yang dialami oleh teman dialognya. ${ }^{21}$ Tujuan dialog antar agama ini adalah dimaksudkna adanya diskusi secara bersama dengan dasar saling mengerti, memahami, dan menghargai atas keyakinannya masing-masing, yang kemudian terjalin kerjasama membangun komunikasi dalam menjalankan keputusan bersama yang dilandasi sikap jujur, terbuka dan komitmen.. ${ }^{22}$

Pesantren sebagai bagian dari masyarakat mempunyai peranan penting untuk menyelenggarakan program dialog antar umat beragama. Pesantren setidaknya membekali santrinya dengan mengadakan beberapa program dialog sebagai berikut: Pertama, program kerjasama antar agama. Program ini dimaksudkan untuk membiasakan diri saling bekerjasama dan memperkuat kerukunan antar umat beragam dengan berbagai berbagai lapisan masyarakat tanpa memandang agama.

Kedua, program pendampingan.Pendampingan atau biasa disebut dengan advokasi adalah salah satu bentuk kegiatan dalam rangka membela, mendukung, atau merekomendasikan. Tujuan dari advokasi adalah untuk menyelesaikan masalah seseorang, dua orang maupun masalah antar kelompok masyakat. Dalam hal ini pesantren memampukan santrinya untuk memfokuskan dirinya dalam berbagai persoalan yang dialami oleh umat beragama.

Ketiga, pesantren menyelenggarakan pelatihan, workshop, diskusi dan seminar untuk para santri bersama antar umat beragama. Tujuannya adalah supaya terjalin komunikasi yang saling memberikan manfaat antar umat beragama. Sehingga terbentuk komunitas yang mampu mendorong para santri memiliki kesadaran penuh yang nantinya menjadi dasar dalam mengarungi kehidupan antar umat beragama.

Keempat, program mabitantar beragama. Mabit antar agama adalah antar pemeluk agama mukim beberapa saat misal umat kristen mukim di pesantren demikian pula sebaliknya santri mukim di perkampungan non-muslim demikian seterusnya untuk saling belajar dan mengenal diantara mereka. Pesantren haruslah terbuka dan menerima tokoh agama yang menginginkan untuk belajar bersama para santri dan mengenal kegiatan pesantren setiap harinya.

${ }^{21}$ Budiyono, Membina kerukunan hidup antar umat beriman, Yogyakarta: Kanisius 1983, hlm. 80-81

${ }^{22}$ Loernard Swider and Paul Mojzas, From The Age Monologue To The Age of Global Dialogue, dalam The Study of Religion In An Age of Global Dialogue, Philadelphia: Temple University Press, 2000 hlm 148. 
Kelima, membuat konten di media tentang kerukunan antar umat beragama. Dalam program ini pesantren memberikan pelatihan terhadap santri untuk dimampukan dalam menerbitkan buletin, buku dan siaran TV maupun media masa lainnya yang bertujuan untuk mengembangkan perdamaian dan dialog antar agama.

Berbagai macam dialog agama diatas menunjukkan bahwa pesantren memandang bahwa pendidikan dialog bagi para santri merupakan persoalan penting untuk bekal bagi para santri dalam mengarungi hidup bermasyarakat nantinya. Melalui dialog santri memperoleh paradigma dan pengalaman baru, yang akan memperkaya dan memampukan mereka untuk menjadi yang terbaik dalam kehidupannya. ${ }^{23}$

Program dialog antar agama yang dilakukan oleh pesantren bertujuan: Pertama,dialog dilakukan bukanlahdalam rangka mencari suatu pembenaran terhadap keyakinannya sendiri, akan tetapi dialogdimaksudkan untuk menambah pengalaman para santri dengan adanyakeberagamaan yangdijadikan sebagai pemampuan diri. $^{24}$ Dengan kemampuan tersebut diharapkan santri dapat mengambil keputusan terbaik dalam menjalani kehidupan yang beragam.

Kedua, dialog dilakukan sebagai usaha untuk saling bertukar pengalaman hidup keberagamaan diantara para santri. Ketiga, dengan dialog para santri bisa mengambil pelajaran bahwa hakikat agama adalah memberikan kedamaian, memberikan perlindungan, dan menebarkan kasih sayang. Pemikiran ini mengarahkan pesantren pada pengembangan pandangan anti eksklusivisme agama lebih pada pandangan yang inklusif bahkan pluralis.Dengan demikian pesantren memberikan pengajaran terhadap santrinya bahwa dialog merupakan salah satu jalan yang efektif dengan tanpa menimbulkan kekerasan dalam memandang adanya keberagaman nilai-nilai dalam kehidupan sosial masyarakat yang meliputi: 1) adanya keinginan untuk saling terbuka dalam hal keyakinan. 2) adanya sikap demokratis artinya dialog adalah salah satu usaha manusia untuk memandang teman dialognya dengan kesetaraan. 3) adanya kesediaan dalam memandang sesuatu dengan sudut pandang teman dialog tanpa membenarkan keyakinannya. 4) dialog bukan suatu perdebatan, yang melihat keyakinan teman

${ }^{23}$ Dian Nafi', Menimba Kearifan Masyarakat, (Yogyakarta: Amwin-institutePustaka Pesantren, 2004), hlm. 178-179

${ }^{24}$ Loernard Swider and Paul Mojzas, From The Age Monologue To The Age of Global Dialogue, dalam The Study of Religion In An Age of Global Dialogue, Philadelphia: Temple University Press, 2000 hlm 147. 
dialog dalam sudut pandang kita. ${ }^{25}$

b. Pendidikan Mediasi Konflik

Sebagai salah satu instrumen resolusi konflik, mediasi bukanlah sesuatu yang baru dalam kehidupan sosial-budaya di negara Indonesia, yang berbagai masalah konflik dapat diselesaikan dengan asas kekeluargaan. Menurut John W. Head, mediasi adalah seseoang yang bertindak memberikan jalan tengah yang artinya seseorang yang dijadikan sebagai "alat transportasi" untuk berkomunikasi antar para pihak, sehingga memberikan pandangan kepada mereka yang bersengketa sehingga dapat dipahami dan didamaikan, tetapi tanggung jawab utamanya adalah perdamaian tercapai berada pada mereka sendiri. Dari pengertiantersebut, mediator dijadikan sebagai "alat transportasi" bagi mereka yang bersengketa untuk berkomunikasi. ${ }^{26}$

Mediasi konflik dimaksudkna untuk menyelesaaikan konflik dengan tanpa kekerasan kekerasan dan meningkatkan keadilan. Oleh karena itu, struktur mediasi konflik harus mengacu dalam memberikan analisa sosial yang dapat memunculkan konflik dan memberikan strategi untuk memberikan pengaruh terhadap struktur sosial. Dari sinilah mediasi konflik diusahakan memberikan pengetahuan dan pemahaman sebab-musabab keadaan sosial yang memicu terjadinya konflik, untuk mengambil tindakan untuk mengurangi pengaruh dan meminimalisir permusuhan. Dengan terbangunnya mediasi konflik ini diharapkan terbentuk struktur yang dapat memenuhi kebutuhan dasar masyakat didalam pengambilan keputusan. Praktek mediasi dimulai dari fakta yang ada bahwa konflik bisa menjadi sangat beragam, sehingga penyelesaiannya membutuhkan banyak yang terlibat didalamnya. Untuk mengetahui tingkat keparahan konflik bisa dilukiskan bahwa konflik akan selalu tumbuh subur dalam kehidupan bermasyarakat dan bersifat tersembunyi. Waktu tersembunyinya suatu konflik bisa berlangsung lama, disebabkan ada suatu perbedaan di tengah masyarakat yang dapat dikelola dengan baik dengan cara mengembalikan masalah konflik kepada tindakan yang ada berdasarkan norma yang ada dan rasa keadilan pada masyarakat.

Disaat keadilan di tengah-tengah masyarakat dilukai maka akan menimbulkan pemicu suatu kekerasan dan konflik akan semakin meningkat. Secara otomatis berbagai informasi tidak lagi memihak kepentingan bersama, melainkan akan menimbulkan

${ }^{25}$ Badru D. Kateregegga dan Dawid W. Shenk, a Moslem and Christian Dialogue (terj) Dialog Islam dan Kristen, (Semarang Putra Muria, 2007), hlm. 16.

${ }^{26}$ Gatot Soemartono, Arbitrase dan Mediasi di Indonesia (Jakarta: PT. Gramedia Pustaka Utama, 2006), hlm. 119-120

148 Vol. 2, No. 2, Juli - Desember 2019 
kecurigaan kelompok satu dengan yang lainnya. Jika hal yang seperti ini tidak segera diambil tindakan dengan baik, maka masyakat akan terjebak terjadinya konflik. Mediasi konflik dapat dilakukan setelah melihat masyarakat jenuh akan adanya konflik dan merindukan perdamaian. ${ }^{27}$

Mediator dalam mediasi konflik sangatlah dibutuhkan. Mediator adalah orang yang mempunyai peranan penting dalam memberikan dorongan terjadinya penyelesaian konflik.Mediator harusnya tidak hanya berfungsi sebagai penengah pada saat konflik terjadi, akan tetapi mediator diharapkan mampu memgupayakan perdamaian jangka panjang. Oleh karena itu, pesantren memberikan pendidikan kepada para santri untuk menjadi seorang mediator yang dapat mewujudkan suatu lingkungan yang tenang untuk melakukan perundingan. Dengan kondisi yang baik diharapkan dapat mempercepat proses penyelesaian konflik yang timbul. Mediator harus dapat menjadi seorang manajer yang memahami kondisi dalam proses perundingan. Maksudnya mediator mampu mengelola persoalan yang dapat memberikan pengaruh terhadap orang-orang yang berkonflik. Mediator suatu waktu dapat merencanakan dan membangun komunikasi mereka, sehingga mereka mengungkapkan gagasaannya dengan sikap terbuka dan tidak menyinggung perasaan orang yang berkonflik lainnya. Mulai dari hal ini secara langsung mediator seharusnya bisa saling bekerjasama dengan berbagai pihak untuk terciptanya keberhasilan perundingan dan terselesaiknnya konflik dengan baik, yaitu dengan cara memberikan bantuan bagi orang yang berselisih untuk mencari jalan penyelesaian konflik.

Secara garis besarnya pesantren dapat membekali santrinya untuk menjadi mediator dengan proses mediasi lima tahap sebagai berikut; pertama, tahap sebelum melakukan mediasi (pra mediasi), tahap ini berisi ushaa untuk mempertemukan pihak-pihak yang sedang berkonflik. Tahapan ini dilakukan dengan sungguhsungguh untuk membangun saling percaya antara satu dengan yang lainnya, yang selanjutnya diusahakan untuk mengumpulkan informasi penyebab terjadinya konflik.Kedua, tahap pendekatan. Pada tahap ini mediator menemui pihak yang berkonflik tidak pada satu tempat tetapi mediator melakukan pertemuan dengan pihak yang berkonflik secara terpisah. Dalam tahap ini mediator menggunakan gaya bahasa yang dapat dipahami oleh pihak yang berkonflik untuk memberikan penjelasan bagaimana konflik dapat terselesaikan.

${ }^{27}$ Muhksin Jamil (ed), Mengelola Konflk Membangun Damai: Teori, Strategidan Implementasi Resolusi Konflk (Semarang: WMC-IAIN Walisongo, 2007) hlm. 8-10 
Ketiga, tahap bercerita. Dalam tahap ini mediator mempersilahkan pihak yang berkonflik untuk menceritakan masalah yang tengah dihadapi. Biasanya dalam penceritaan ini kelihatan sangat sensitif, oleh karena itu mediator harus cerdas dalam membangun suasana agar tetap nyaman dan tenang. Pada kesempatan tertentu, mediator memprafrasekan pembicaraan dari para pihak yang terlibat konflik dengan dingin tanpa mengurangi substansi dialog. Dengan demikian mediator harus mau menjadi seorang pendengar yang baik dan aktif. Menjadi pendengar yang baik lagi aktif bukanlah keterampilan yang mudah dibutuhkan konsentrasi dan kefokusan mediator masalah yang dibicarakan. Tidak hanya menjadi pendengar yang baik lagi aktif, mediator mencatat dan mendaftar persoalan-persoalan yang menjadi sebab terjadinya konflik diantara para pihak. Catatan dan daftar masalah ini sangat penting untuk menjadi tolak ukur sampai mana konflik itu mencederai masing-masing pihak. Dalam tahap ini membutuhkan beberapa waktu dan tidak bisa dengan sekali selesai.Keempat,tahap penyelesaian masalah. Setelah tahap mengungkapkan persoalan telah usai, kemudian dilanjut dengan upaya penyelesaian masalah secara bersama. Catatan daftar permasalah milik mediator diceritakan kembali kepada pihak yang berkonflik, supaya para pihak yang berkonflik mengerti permasalah apa yang tengah dihadapi.

Demikian ini diharapkan akan adanya prakarsa untuk berdamai diantara para pihak. Pada tahapan ini seringkali menajdi tahapan paling sulit, dikarenakan para pihak biasanya masih merasa dirinya yang paling benar dan menang. Kelima,tahap mewujudkan kesepakatan. Tahapan ini moderator menjelaskan berbagai hal yang telah disepakati para pihak. Misal dalam konflik sosial kemasyarkatan; kesapakatan saling menjaga keamanan, saling menjaga ketertiban, menghormati antar pemeluk agama, tidak saling mengintimidasi atau mendiskriminasi kelompok tertentu apalagi terhadap yang minoritas.Kemudian mediator memastikan bahwa hal telah disepakati tersebut membicarakan hal-hal yang bisa diukur, bisa dilaksnakan, menjawab permasalahan, terlibatnya semua pihak yang berkonflik dan batasan-batasan dilaksanakannya kesepakatan tersebut. Dan hal yang lebih penting dari itu adalah usaha mediator dalam memberikan dorongan kepada para pihak untuk membuat kesepakatan yang mencakup dalam penanganan permasalahan yang muncul nantinya dan meminta para pihak untuk mencatat saling menyokong kesepakatan tersebut dan para pihak diminta untuk membubuhkan tanda tangan.

Membangun komunikasi dengan para pihak dalam proses 
mediasi sangatlah penting untuk dilakukan. Hal ini dinamakan dengan parafrase.Parafrasae adalah kemampuan untuk menanggulangi pernyataan-pernyataan yang menghasut. Parafase ini dilandasi oleh kecakapan dalam mengubah ucapan yang menghina, memojokkan dan memfitnah dari salah satu pihak dengan pembahasaan yang netral dan baik.Misalnya kalimat "dia menipu" menjadi "anda menggunakan cara pandang berbeda dalam masalah ini.”Dan ketika diskusi terjadi saling menghina dan melontarkan hujatan-hujatan yang tidak baik, mediator dapat memberikan masukan atau gagasan yang lain. Apabila terjadi luapan emosi yang tidak terkendali, para pihak dapat dipertemukan dengan secara terpisah tapi tetap dalam proses mediasi

Parafase adalah sebuah keterampilan yang efektif dan efisien yang digunakan dalam mediasi konflik. Hal ini dikarenakan parafrase memberikan arahan pemahaman mediator ke para pihak yang terlibat. Parafrase mengarahkan pada pendalaman pembicaraan. Maksudnya parafrase sebagai umpan untuk memunculkan tanggapan yang spontan dari orang yang diajak bicara. Parafrase dapat menurunkan ritme pembicaraan diantara para pihak, memberikan pertolongan kepada para pihak untuk mengungkapkan gagasan atau pandangan mereka masing-masing. Parafrase juga memiliki fungsi untuk mempercantik pernyataanpernyataan yang cenderung tinggi, kasar, keras dan mematahkan menjadi pernyataan yang tidak memihak dan mempertahankan inti persoalan. Disamping itu, parafrase juga meredam pernyataan yang cenderung emosional menjadi lebih halus, dan mempermudah salah satu pihak menjadi pendengar dan memahami pembicaraan lawan bicaranya. ${ }^{28}$

Sebaiknya parafrase mempunyai kreteria sebagai berikut; (1) mengulang apa yang telah dikatakan orang lain dengan kata-kata sendiri. Maksudnya mediator tidak hanya sebagai pendengar yang baik tetapi juga fokus untuk memparafrasekan apa yang dibicarakan.(2)parafrase adalah sebuah ringkasan pernyataanpernyataan yang disampaikan oleh para pihak, jadi tidak boleh terlalu panjang dari pernyataan para pihak.(3)tidak hanya mengulang sebuah pernyataan, tetapi parafrase adalah refleksi arti dari pernyataan para pihak.(4) jangan sampai parafrase itu menghakimi atau menilai tetapi memberikan gambaran apa saja yang telah dinyatakan. Sehingga parafrase tidak hanya menggambarkan permasalahan-permasalah yang terjadi pada para pihak.

${ }^{28}$ Ronald S. Kraibill, Panduan Mediator; Terampil Membangun Perdamaian (Jogjakarta; Kanisius, 2006) hlm. 145 
Tidak hanya memparafrasekan saja, tetapi diharapkan mediator membuat sebuah catatan sebagai ringakasan dari pernyataan para pihak. Ringkasan berfungsi untuk melihat lagi substansi yang telah nyatakan oleh para pihak. Dengan hal ini, mediator dapat menjelaskan pada para pihak bahwa mediator telah memahami apa yang menjadi arah pembicaraan yang disampaikan oleh para pihak. Supaya bisa mencapai sebagaimana hal tersebut, menjadi pendengar yang baik merupakan syarat seorang mediator. Dikarenakan menjadi pendengar yang baik berarti ada pengakuan yang mendalam dan menghormati para pihak yang terlibat konflik. Termasuk dari pemberdayaan adalah menjadi pendengar yang baik dari pernyataan para pihak yang telibat konflik, dikarenakan hal itu juga merupakan ajakan dan dorongan dalam pengungkapan diri dengan mendalam dari para pihak yang berkonflik.

Karakteristik yang harus ada pada mediator adalah (1) menjaga kerahasian, yaitu seluruh yang kegiatan yang dilakukan oleh mediator dalam menangani para pihak yang berkonflik harus dijaga kerahasiannya tidak boleh dipublikasikan kepada khalayak umum. (2) bersifat sukarela bukan karena keterpaksaan membantu pihak yang terlibat konflik, (3) memberdayakan, maksudnya mediator memampukan para pihak untuk berinteraksi dalam menyelesaikan permasalahannya sendiri.(4) bersikap netral, mediator berperan hanya sebagai fasilitator para pihak, bukan perperan layaknya seorang hakim yang memutuskan benar atau salahnya permasalahan para pihak yang terlibat konflik, atau bahkan memaksakan pendapatnya sendiri kepada para pihak. ${ }^{29}$

Dari pemaparan tersebut dapat dinyatakan bahwa peranan pesantren dalam mendidik para santri untuk menjadi mediator dalam memediasi konflik merupakan usaha untuk memampukan para santri untuk bisa turut serta secara aktif dalam menyelesaikan konflik yang terjadi di masyarakat.

c. Pendidikan perdamaian

Pendidikan perdamaian merupakan hal penting yang perlu dilakukan oleh Pesantren dalam membangun kesadaran akan kehidupan yang damai. Pendidikan adalah sarana untuk meneruskan nilai-nilai luhur yang telah diwariskan oleh nenek moyang secara damai. Ada lima hal yang pening mengapa pendidikan diikut sertakan dalam bahasan pembangunan perdamaian. Pertama, pendidikan adalah tempat peran serta masyarakat dalam pendidikan. Kedua, pendidikan adalah tempat

${ }^{29}$ Muksin Jamil (ed), Mengelola Konflk Membangun Damai; Teori, Strategi dan Implementasi Resolusi Konflk (Semarang; WMC IAIN Walisongo SMG, 2007) hlm. 111-115 
masyarakat untuk menikmati hasil pembangunan. Ketiga, pendidikan adalah tempat perubahan status sosial yang damai dan terbuka. Tidak hanya orang yang kaya saja yang dapat mengubah dirinya menjadi kelas menengah keatas melalui pendidikan. Keempat, pendidikan adalah tempat membentuk karakter kepribadian masyarakat melalui pengembangan dan pewarisan nilai-nilai luhur suatu komunitas. Kelima, pendidikan adalah tempat untuk berusaha menjadikan peserta didik sebagai pribadi yang bertanggung jawab terhadapa baik tanggung jawab sosial, budaya, politik maupun hukum. ${ }^{30}$

Pendidikan perdamaian yang diprogramkan pesantren bertujuan agar santri dan masyarakat sekitar berdaya mempunyai kemampuan untuk mengolah permasalahnya sendiri, tidak bergantung pada orang lain.Menurut Lisa Schirch masyarakat yang mampu mengatur permasalahannya sendiri maka masyarakat akan bisa menentukan keputusan-keputusanny sendiri, dan lebih mempunyai ketahanan dan tidak gampang terpengaruh oleh keadaan sosial, politik yang ada. ${ }^{31}$

Pesantren dapat mengadakan program pendidikan perdamaian sebagai berikut:

1) Pelatihan Manajemen Konflik

Manajemen konflik merupakan salah satu cara yang dilakukan oleh seseorang untuk merespon dan menyelesaikan konflik. Dengan diadakannya program pelatihan manajemen konflik, santri diharapkan; (1) membangun kesiapsiagaan santri dalam kehidupan sosial dan meningkatkan kemampuan mereka dalam mengelola konflik secara mandiri.(2) santri diharapkan sadar akan pentingnya pengelolaan konflik dan penyelesaiannya dengan tanpa ada kekerasan didalam.

Model pelatihan yang diterapkan dalam pelatihan manajemen konflik ini dengan model pendidikan popular. Pendidikan popular merupakan sebuah model pendidikan yang berlangsung pada setiap harinya yang berada di masyarakat untuk memperbaiki dan meningkatkan kualitas kehidupan masyarakat. Pendidikan ini terselenggara dengan mengamati keadaan nyata masyarakat. Tujuan dari model pendidikan popular ini adalah melatih seseorang belajar dari pengalamannya sendiri. ${ }^{32}$ hlm. 51

${ }^{30}$ Dian Nafi', Menimba Kearifan Masyarakat... hlm. 224

${ }^{31}$ Lisa Schirch, Strategis Peace Building, (USA; Goodbook, Intercourse PA. 17534),

${ }^{32}$ Mansour Faqih, Pendidikan Populer: Panduan Pendidikan Metode Kritis Transformatif

(Yogjakarta:

INSIST Press, 2004) hlm. 30

153 Vol. 2, No. 2, Juli - Desember 2019 
2) Program Pedidikan Perdamaian bagi pemuda dan remaja di sekitar pesantren.

Pentingnya pesantren mempunyai program pendidikan perdamaian bagi para pemuda dan remaja di sekitar pesantren yang bertujuan untuk; (1)memberikan pemahaman tentang pentingnya perdamaian bagi pemuda dan remajadi sekitar pesantren,(2) Mewujudkan kebersinambungan kegiatan dan peran pemuda dan remaja dalam mengembangkan perdamaian agar tercipta saling memahami, menurunkan kecurigaan, dan berprasangka buruk terhadap sesama umat dalam kehidupan bermasayarakat.(3) Terciptanya pemuda dan remaja yang mampu mengembangkan perdamaian di masa yang akan datang.

3) Pengembangan Perdamaian Melalui Pendirian Lembaga

Pendirian lembaga dalam pesantren memiliki peran untuk memperkuat pesantren dalam mengembangkan perdamaian. Lembaga yang didirikan nanti merupakan lembaga yang mempunyai visi dan misi sesuai dengan pesantren.Dan nantinya lembaga yang didirikan ini dimampukan untuk berdiri sendiri. Misal pesantren mendirikan lembaga khusus untuk perempuan yang memiliki program persolan perempuan seperti hak reproduksi perempuan, kesetaraan gender dan KDRT (Kekerasan Dalam Rumah Tangga).Pesantren mendirikan lembaga Pendidikan Anak Usia Dini (PAUD) untuk persemaian perdamaian sejak dini.

Dari berbagai kegiatan pendidikan perdamaian yang dilakukan oleh pesantren tersebut diarahkan agar santri dan masyarakat terlibat aktif dalam persoalan perdamaian, membantu komunitas yang lemah dan terpinggirkan, memberikan solusi atas pelbagai masalah, dan pendidikan yang diselenggarakan berbasis kesetaraan sehingga tidak ada yang mendominasi dalam pendidikan tersebut.

\section{B. Penutup}

Pesantren mempunyai potensi yang sangat besar dalam mendidik santri dan masyarakat Indonesia yang plural ini dalam membangun kehidupan yang damai.Pesantren mempunyai peranan yang sangat signifikan untuk melakukan dan mendorong penyelesaian konflik yang terjadi di masyarakat dengan berbagai macam kegiatan yang dibungkus dalam pendidikan resolusi konflik. Peran pesantren dalam menyelenggarakan pendidikan resolusi konflik merupakan sumbangan yang sangat berharga untuk keberlangsungan perdamaian tanpa terjadi kekerasan disaat bangsa Indonesia yang multikultural ini mengalami berbagai konflik sosial keagaman yang sangat memprihatinkan. 


\section{REFERENSI}

Andito (ed.), Atas Nama Agama, (Bandung: pustaka Hidayah, 1998)

Anwar, Dewi Fortuna dkk (ed.), Konflik Kekerasan Internal: Tinjauan Sejarah, Ekonomi, Politik dan Kebijakan di Asia Pasifik (Jakarta: Yayasan Obor Indonesia-LIPI dan LASEMA-CNRS, 2004)

Asmani, Jamal Ma'mur, Dialektika Pesantren Dengan Tuntutan Zaman Dalam Menggagas Oesantren Masa Depan, Geliat Suara Santri Untuk Indonesia Baru (Yogyakarta: Qirtas, 2003)

Buchanan, Cate (ed.), Pengelolaan Konflik di Indonesia: Sebuah Analisis Konflik di Maluku, Papua dan Poso (Jakarta: LIPI dan Current Asia and the Centre for Humanitarian Dialogue, 2011)

Budiyono, Membina kerukunan hidup antar umat beriman, (Yogyakarta: Kanisius 1983)

Cahyono, Heru, Konflik di Kalbar dan Kalteng Sebuah Perbandingan Masyarakat Indonesia, (Jilid XXX No 2 2004)

Deutsch Morton, and Peter T. Coleman, The Handbook of Conflict Resolution, Theory and Practice. (San Fransisco: Jossey-Bass Publisher, 2006)

Faqih, Mansour, Pendidikan Populer: Panduan Pendidikan Metode Kritis Transformatif (Yogjakarta: INSIST Press, 2004)

Fiadjoe, Albert, Alternative Dispute Resolution: Developing Word Perspective (London: Covendish Publishing Limited, 2004)

Fisher, Simon, dkk. Mengelola Konflik: Keterampilan \& Strategi Untuk Bertindak. (Jakarta: The British Council, 2001)

Haedari, Amin, Masa Depan Pesantren Dalam Tantangan Modernitas dan Tantangan Kompleksistas Global (Jakarta: IRD Press, 2006)

Hunt, M.P, and Metcalf, Ratio and inquary on Society's Closed Areas, in Educating The Democratic Mind (W. Partner). (New York: State University of New York Press, 1996).

Jamil, Muhksin (ed), Mengelola Konflk Membangun Damai: Teori, Strategidan Implementasi Resolusi Konflk (Semarang: WMC-IAIN Walisongo, 2007) 
Kateregegga, Badru D. dan Dawid W. Shenk, A Moslem And Christian Dialogue (terj) Dialog Islam dan Kristen, (Semarang Putra Muria, 2007)

Khamad, Dadang, Sosiologi Agama, (Bandung: Remaja Rosdakarya, 2004)

Kontras, Laporan Pemantauan Pemolisian \& Hak atas Berkeyakinan, Beragama, dan Beribadah (Jamaah Ahmadiyah Indonesia di Manis Lor, Ciputat, Cikeusik \& Jemaat Kristen HKBP Ciketing dan GKI Taman Yasmin (Jakarta, 2012)

Kraibill, Ronald S., Panduan Mediator; Terampil Membangun Perdamaian (Jogjakarta; Kanisius, 2006)

Lederach, John Paul, Conflict Transformation (Intercourse: Good Books, 2003)

Levine, Webster Dictionary, (1998)

Liliweri, Alo, Prasangka dan Konflki: Komunikasi Lintas Budaya Masyarakat Multikultur (Yogjakarta: LKIS, 2005)

Mahfudz, Sahal, Nuansa Fiqh Sosial (Yogyakarta; LkiS, 1994)

Mastuhu, Dinamika Sistem Pendidikan Pesantren; Suatu Kajian Tentang Unsur Dan Nilai Sistem Pendidikan Pesantren (Jakarta: INIS, 1994)

Mindes, Gayle. Teaching Young Children Social Studies (United States of America: Praeger Publishers. 2006)

Nafi', Dian (dkk), Praksis Pembelajaran Pesantren (Yogyakarta: Forum Pesantren dan Institute For Training and Development (ITD), 2007)

, Menimba Kearifan Masyarakat, (Yogyakarta: Amwininstitute-Pustaka Pesantren, 2004)

Rahman, Budhi Munawar, Pluralism Dan Dialog Antara Agama:Paradigma Teologi Eksklusif, Inklusif dan Pluralis , dalam Abdul Hakim dan Yudi Latif (peny), Bayang-bayang Fanaitisme; Esai-Esai untuk mengenang Nurcholis Madjid, (Jakarta : Paramadina, 2007)

Scannell, The Big Book of Conflict Resolution Games. (United States of America: McGraw - Hill Companies, Inc 2010) 
Schirch, Lisa, Strategis Peace Building, (USA; Goodbook, Intercourse PA. 17534)

Soemartono, Gatot, Arbitrase dan Mediasi di Indonesia (Jakarta: PT. Gramedia Pustaka Utama, 2006)

Swider, Loernard and Paul Mojzas, From The Age Monologue To The Age of Global Dialogue, dalam The Study of Religion In An Age of Global Dialogue, (Philadelphia: Temple University Press, 2000) 